University of Wollongong

Research Online

Faculty of Commerce - Papers (Archive)

Faculty of Business and Law

$1-6-2007$

\title{
What motivates which volunteers? Psychographic heterogeneity among volunteers in Australia
}

Sara Dolnicar

University of Wollongong, s.dolnicar@uq.edu.au

Melanie J. Randle

University of Wollongong, mrandle@uow.edu.au

Follow this and additional works at: https://ro.uow.edu.au/commpapers

Part of the Business Commons, and the Social and Behavioral Sciences Commons

\section{Recommended Citation}

Dolnicar, Sara and Randle, Melanie J.: What motivates which volunteers? Psychographic heterogeneity among volunteers in Australia 2007.

https://ro.uow.edu.au/commpapers/372

Research Online is the open access institutional repository for the University of Wollongong. For further information contact the UOW Library: research-pubs@uow.edu.au 


\title{
What motivates which volunteers? Psychographic heterogeneity among volunteers in Australia
}

\begin{abstract}
Six psychographic segments of volunteers in Australia are constructed on the basis of their volunteering motivations. The resulting segments include "classic volunteers", whose motivations are three-fold: doing something worthwhile, personal satisfaction, and helping others. "Dedicated volunteers" perceive each one of the motives for volunteering as relevant, while "personally involved volunteers" donate time because of someone they know in the organization, most likely their child. "Volunteers for personal satisfaction" and "altruists" primarily wish to help others, and finally," niche volunteers" typically have fewer and more specific drivers motivating them to donate time, for example, to gain work experience. The segments are externally validated and demonstrate significantly different socio-demographic profiles. Consequently, it seems that motivation-based data-driven market segmentation represents a useful way of gaining insight into heterogeneity amongst volunteers. Such insight can be used by volunteering organizations to more effectively target segments with customized messages.
\end{abstract}

\section{Keywords}

segmentation, volunteering, nonprofit marketing

\section{Disciplines}

Business | Social and Behavioral Sciences

\section{Publication Details}

Dolnicar, S. and Randle, M. (2007). What motivates which volunteers? Psychographic heterogeneity among Volunteers in Australia. Voluntas: International Journal of Voluntary and Nonprofit Organizations, 18(2), 135-155. 


\title{
What Motivates Which Volunteers?
}

\section{Psychographic Heterogeneity Among Volunteers in Australia}

\author{
Sara Dolnicar ${ }^{1,2} \&$ Melanie Randle $e^{1,3}$
}

\author{
Correspondence: \\ Melanie Randle \\ School of Management and Marketing \\ University of Wollongong \\ Northfields Avenue \\ Wollongong NSW 2522 Australia \\ Phone: +61242215528 \\ Fax: +61242214154 \\ Email:mjr46@uow.edu.au
}

Suggested Running Head: What Motivates Which Volunteers?

\footnotetext{
${ }^{1}$ Authors listed in alphabetical order. Authors have contributed equally to this article.

${ }^{2}$ School of Management and Marketing, University of Wollongong, Wollongong NSW Australia

${ }^{3}$ School of Management and Marketing, University of Wollongong, Wollongong NSW Australia
} 


\begin{abstract}
$\underline{\text { Abstract }}$
Six psychographic segments of volunteers in Australia are constructed on the basis of their volunteering motivations. The resulting segments include "classic volunteers", whose motivations are three-fold: doing something worthwhile, personal satisfaction, and helping others. "Dedicated volunteers" perceive each one of the motives for volunteering as relevant, while "personally involved volunteers" donate time because of someone they know in the organization, most likely their child. "Volunteers for personal satisfaction" and "altruists" primarily wish to help others, and finally," niche volunteers" typically have fewer and more specific drivers motivating them to donate time, for example, to gain work experience. The segments are externally validated and demonstrate significantly different socio-demographic profiles. Consequently, it seems that motivation-based data-driven market segmentation represents a useful way of gaining insight into heterogeneity amongst volunteers. Such insight can be used by volunteering organizations to more effectively target segments with customized messages.
\end{abstract}

Key words: segmentation, volunteering, nonprofit marketing 
In Australia, the volunteering sector has an estimated dollar value of 42 billion Australian dollars (approximately 32 billion US dollars) per annum with 4.4 million Australians contributing a total of 704 million hours (Volunteering Australia, 2001). Increasingly, nonprofit organizations are being expected to provide services and activities which have traditionally been the responsibility of government (Bales, 1996; Courtney, 1994; Wilson \& Pimm, 1996). This, combined with reductions in funding is increasing the demand for unpaid workers (Wymer, 1997). The immense and growing contribution of the volunteering sector has led to substantial research in various disciplines investigating different aspects of the volunteering phenomenon.

Despite extensive prior research on volunteering, data-based studies of variety amongst volunteers seem to be limited. Descriptions of volunteers are typically either based on average evaluations of all volunteers or on simple grouping criteria like sex and age. Neither of these approaches provides adequate insight into the market structure which needed to help volunteering organizations recruit new members in times of increasing competition (Courtney, 1994; Riecken, Babakus, \& Yavas, 1994). Other methods need to be explored to identify homogeneous groupings of volunteers that can be addressed with targeted messages to improve recruitment rates.

This research gap has been explicitly mentioned by numerous researchers. Chinman \& Wandersman (1999, p. 61) highlight the core problem of the present study by stating: "Often, voluntary organizations would like to attract a diverse membership (e.g., age, gender, ethnicity). [...] Benefits and costs may be mediating variables between demographic variables and participation. Therefore, volunteer organization leaders may be able to improve participation by providing the benefits a specific group wants most and by minimizing the effects of the costs that a specific group dislikes the most". Reed \& Selbee (2000, p. 588-589) support the need for more research in this area by saying: "These findings [...] prompt the 
questions of (sub)cultures of generosity. Are there particular social settings (such as small urban or rural communities in certain regional contexts) where the unique combination of (a) prevalent norms, values, social networks, and civic structures and (b) the blend of both opportunity and need for helping [...] produce conditions that are especially favorable to volunteering and that elicit such behavior selectively from individuals who are heterogeneous in most other respects? And what is the importance of personality factors relative to subcultural elements?" More generally, Bussell \& Forbes (2002, p. 248) recommend that "Establishing meaningful segments of the volunteer 'market' could lead to more effective targeting of particular groups and, thus, more effective recruitment and retention strategies." The aim of this paper is to fill this research gap and construct market segments among volunteers based on their motivation to donate time to volunteering organizations. The underlying assumption is that, if such segments can be identified and understood, customized marketing messages can be developed to maximize the impact of appeals to volunteers and ultimately increase rates of involvement within the community.

For the purposes of this article the definition of volunteering to be used is that adopted by the Australian Bureau of Statistics for the Voluntary Work Survey 2000, that is: "someone who, in the last 12 months, willingly gave unpaid help, in the form of time, service or skills, through an organization or group" (Australian Bureau of Statistics, 2001, p. 3).

\section{$\underline{\text { Prior Research }}$}

The available information on the phenomenon of volunteering has grown enormously in recent decades. In considering the voluminous literature available, for the purposes of this investigation the review of prior research has been focused on two key aspects of volunteering - motivations for volunteering and attempts at segmenting the volunteer market.

\section{$\underline{\text { Motivations }}$}


Central to the marketing concept is harmonizing customer needs and organizations' strengths (McDonald, 2002). Therefore understanding why people volunteer, or their motivations, can help understand what they are looking for from the volunteering experience and help managers tailor the volunteering offering to better suit these needs. Numerous studies have attempted to understand the motivations of volunteers and the models proposed to do this have ranged from unidimensional to the more complex five- and six-factor frameworks. At its most simplistic volunteering has been explained as people wanting to help others, that is, that people's motivations are at their core, altruistic (Bussell \& Forbes, 2002). However there has also been significant research which suggests that while altruism may be present in many types of volunteering, people are ultimately motivated by a second broad group of egotistic factors, that is, by the benefits they receive from being involved (for example Hibbert, Piacentini, \& Dajani, 2003). Smith, Macauley \& Associates (1980) go even further to suggest that volunteers are motivated solely by their own interests rather than any form of altruism. The majority of studies, however, support the notion that volunteering motivations are multifaceted, that is, that they occur in combination with each other rather than in isolation (see for example Rehberg, 2005).

Clary, Snyder \& Ridge (1992) took a functional approach and developed a six-factor model of motivations. According to functional theory, individuals volunteer in order to satisfy underlying psychological and social needs and goals, that is, to meet certain needs, to reach certain aims or to satisfy certain motives. They argue that people can perform the same type of volunteering activity but for very different reasons. Their "Volunteer Functions Inventory" (VFI) identifies six functions relevant to volunteering: values, career, understanding, social, enhancement and protective. A number of US-based studies have since been conducted which offer support for the VFI's validity and reliability (Clary \& Snyder, 1999; Clary, Snyder, \& Ridge, 1992), psychometric qualities (Clary, Snyder, \& Stukas, 1996) and practical relevance 
(Clary et al., 1998), and has also proven an effective measure of motivations in other countries, for example Italy (Marta, Guglielmetti, \& Pozzi, 2006). However the VFI has been criticized recently by Greenslade \& White (2005) for its narrow approach which only considers the benefits of volunteering and fails to take into account other decision making factors such as control factors and behavioral costs.

Liao-Troth \& Dunn (1999) took a different approach by extending Anderson \& Moore's (1978) work on motivation and investigating whether volunteer managers' perceptions of motivations differed from actual motivations as reported by volunteers in Anderson \& Moore's study 20 years earlier. Despite the various limitations of the study, they found little difference in the perceptions of motivations of volunteering managers from volunteers themselves and noted the benefits of these consistencies in developing volunteering programs that are rewarding and satisfying for volunteers.

Another more recent approach to understanding volunteering has been the use of a more generic model of behavior, the Theory of Planned Behavior (Ajzen, 1988), to explain the relationship between attitudes, social norms and perceived behavioral control, and the way these three constructs combine to influence volunteering behavior. This approach has been found to be superior to Clary \& Snyder's VFI in its ability to predict above-average participation in volunteering activities (Greenslade \& White, 2005).

While there have been many prior studies of volunteer motivations they have received criticism because of various limitations in their sampling and measurement techniques (Okun, Barr, \& Herzog, 1998). Although there are many conflicting approaches and findings in the study of volunteering motivations, the one thing that researchers do seem to agree upon is that a nonprofit organization must understand and continually re-evaluate its volunteer base in terms of underlying motivations (Hibbert, Piacentini, \& Dajani, 2003) and needs (Heinz \& 
Robinson, 1999) in order to continue delivering an offering that will meet their needs better than the competing alternatives.

\section{$\underline{\text { Segmentation }}$}

Market segmentation is a standard and well known concept in strategic marketing. The objective is to identify subgroups of individuals who are similar to each other with regard to some predefined criterion. In the case of a priori (Mazanec, 2000) or commonsense segmentation (Dolnicar, 2004), criteria such as age, gender or income can be used to group individuals and determine if the resulting subgroups offer better marketing opportunities than the total market. Alternatively, if there is no clear assumption about which single criteria would be valuable for grouping, a set of variables can be used in a posteriori (Mazanec, 2000) or data-driven segmentation (Dolnicar, 2004). For example, one of the most frequently used bases for data-driven segmentation is psychographic characteristics. In this case motivations, benefits or beliefs are used to groups individuals.

In the area of volunteering, most researchers acknowledge that volunteers are extremely heterogeneous (Bussell \& Forbes, 2002; Wilson \& Pimm, 1996) and a significant number of studies have investigated a wide variety of characteristics of volunteers and their association with volunteering behavior.

Since the 1970s the value of segmentation for nonprofits has been emphasized by social marketers because it not only identifies effective target markets but also helps develop effective programs to reach these markets (Kotler, 1975). For the most part, attempts at categorizing and describing volunteers have been done by using simple grouping criteria or by segmenting volunteers a priori.

In recent decades numerous studies have assumed volunteers can be segmented based on simple demographic variables. Certain characteristics have been strongly and consistently 
linked with volunteering behavior such as education (McPherson \& Rotolo, 1996), employment status (Curtis, Grabb, \& Baer, 1992), and income (Menchik \& Weisbrod, 1987; Smith, 1994). Other demographic and attitudinal variables, for example religion (Berger, 2006; Yeung, 2004), have been less clearly correlated with voluntary participation. However other studies have also demonstrated the limited potential of using simple demographic and attitudinal variables to predict philanthropic behavior (Ordway, 2000). The profile of likely volunteers can differ significantly depending on the type of charity being studied (Shelley \& Polonsky, 2002) so the applicability of these results across different volunteering organizations is somewhat limited.

Lemon, Palisi \& Jacobson (1972) proposed that those within socially determined dominant statuses were more likely to volunteer than those who are not, for example US research indicates this is people who are college educated, middle-aged, white, middle class (Smith, 1994). More recent attempts at segmenting the market have included Heidrich (1990) who used the roles volunteers perform in the organization as a base, demonstrating significant lifestyle and socio-demographic profiles; and Wymer $(1997 ;$, 2003) who used a number of factors including demographics, personality variables, values, facilitation, and intensity of service to identify various homogeneous subgroups for the purposes of target marketing. The problem with these previous a priori segmentation attempts is that they have, for the most part, used criteria which were assumed to split volunteers into homogeneous subgroups. That is, they have essentially represented the researcher's "guess" as to what might discriminate volunteers from other groups. Adding to this is the seemingly contradictory findings emerging from the many different studies conducted with different samples, in different countries, and with different methodologies, which has made it difficult for managers to use the information for recruiting purposes with any degree of confidence. 
Only a few studies have taken a more advanced, a posteriori, approach to volunteer segmentation by investigating segments in a data-driven manner, taking into account an entire set of information. Ewing et al. (2002) took a macro-economic view of volunteering in the US and segmented volunteers according to their needs and motivations. They suggested that by continually monitoring the cyclical changes in the macro-economy and developing alternate marketing strategies, nonprofit organizations can maximize volunteer participation even in times of economic downturn. Shelly \& Polonsky (2002) also used motivations to segment Australian health volunteers but found that motivations for volunteering did not differ by gender or age. They, in fact, go further to recommend that generic promotional and recruitment messages would be equally effective for all volunteers.

In his comprehensive review of research on volunteering Smith (1994) comments on the overly simplistic and narrow approach taken by much of the prior research. More recently, Wymer (2003) also notes: "Future studies which add to the knowledge of how sub-groups of volunteers differ will enrich the understanding of volunteerism in general and of those subgroups under examination in particular" (p. 280).

While prior segmentation attempts have provided some limited insight, the authors propose a new data driven (a posteriori, post-hoc) market segmentation study which extends this stream of research by taking a methodology which has proven extremely valuable in commercial marketing studies and applying it to the volunteering sector. Essentially, it uses motivations as a basis for developing homogenous subgroups of volunteers within a national sample of Australian volunteers. It is anticipated that these subgroups will represent useful targets for specific recruitment messages, in turn facilitating more effective marketing campaigns. 


\section{Empirical Study}

\section{$\underline{\text { Data }}$}

The analysis is based on a Confidentialized Unit Record File (CURF) that was provided by the Australian Bureau of Statistics (ABS).

The data was collected from a national survey of volunteer work conducted by the Australian Bureau of Statistics over four quarters in 2000. Private dwellings were randomly selected and one adult per dwelling was personally interviewed by a trained ABS interviewer, answering questions in relation to themselves plus other members of the household. Information was obtained from 12,900 individuals - a response rate of 88 percent (Australian Bureau of Statistics, 2001).

The data is analyzed in its weighted form, thus allowing for statements representative for the entire population of Australian volunteers. The data set includes socio-demographic information (for example age, sex, marital status, education, country of birth, occupation, income) about the respondents and psychographic and behavioral information related to volunteering activities (for instance, the number of organizations for which each individual volunteers, motivations for volunteering, expenses incurred by volunteering activities, and length of time since first volunteering).

\section{$\underline{\text { Descriptive Analysis }}$}

The Voluntary Work Survey 2000 (Australian Bureau of Statistics, 2001) provides a picture of volunteering in Australia and how it has changed in recent years. Between 1995 and 2000 the percentage of Australian adults involved in voluntary activities grew by 8 percent (from 24 to 32 percent). Volunteers contributed over 704 million hours of voluntary work in 2000, 
an increase of almost 200 million from 1995; however the average hours worked per week has remained stable.

The Voluntary Work Survey 2000 also provides a comprehensive socio-demographic profile of Australian volunteers (Australian Bureau of Statistics, 2001). Australians are more likely to volunteer if they live in non-metropolitan areas, are female, aged between 35-44, have dependent children, were born in Australia, and are employed in professional occupations. Two thirds of volunteers work for one organization only and two types of organizations account for almost half of all volunteers: community/welfare and sporting/recreation.

On average volunteers donate 1.4 hours per week or 72 hours per year and 40 percent have been volunteering with the same type of organizations for six years or more. Men are more likely to be involved in sporting/recreational organizations and emergency services, whereas women are more likely to be involved in community/welfare and educational organizations.

\section{$\underline{\text { Investigating Data-driven Segments Among Volunteers }}$}

The starting point for the analysis of market segments among volunteers is a binary data set including 4,267 respondents and 12 variables. The 12 variables are statements about what might motivate volunteers to donate their time for a volunteering organization and included for the social contact, to gain personal satisfaction, because of personal/family involvement, because of religious beliefs, to be active, to learn new skills, to do something worthwhile, to help others/the community, to gain work experience, to use their own skills or experience, because they felt obliged, or it just happened. Respondents were asked to answer whether each one of the 12 statements does or does not apply to them.

The volunteer motivations data was partitioned using topology representing networks (TRN, Martinetz \& Schulten, 1994). This is a technique that assigns each respondent to the group or segment that contains members most similar to that person. This procedure was chosen 
because it emerged as highly stable partitioning technique in a comparative study conducted with artificial segmentation data (Buchta, Dimitriadou, Dolnicar, Leisch, \& Weingessel, 1997). Essentially, TRNs represent a non-hierarchical exploratory grouping technique similar to online $k$-means (for explanations of classic clustering algorithms see, for instance, Everitt, Landau, \& Leese, 2001), but which, as opposed to $k$-means, allows for neighborhood learning. Six segments emerged as most stable. It should be noted at this point, that determining the optimal number of clusters in market segmentation remains an unsolved problem. A wide variety of approaches have been suggested in the past. The authors have chosen to use the stability of segmentation solutions as the relevant criterion. Therefore, 30 replications of each cluster numbered between 3 and 10 were computed (270 independent topology representing networks in total). Within each number of clusters the pairs of respondents who were repeatedly assigned to the same segment were counted. The higher this number, the more stable the solution for a particular number of clusters. Euclidean distance forms the basis of the partitioning validation undertaken and, as mentioned previously, six segments were found to render the most stable grouping of volunteers.

Figure 1 illustrates the resulting segments by comparing the percentage of segment members who agree with the respective motivation to volunteer (the grey columns) to the total sample average of agreement (black horizontal lines), ignoring heterogeneity of motivations. The black horizontal lines consequently characterize the average Australian volunteer. 

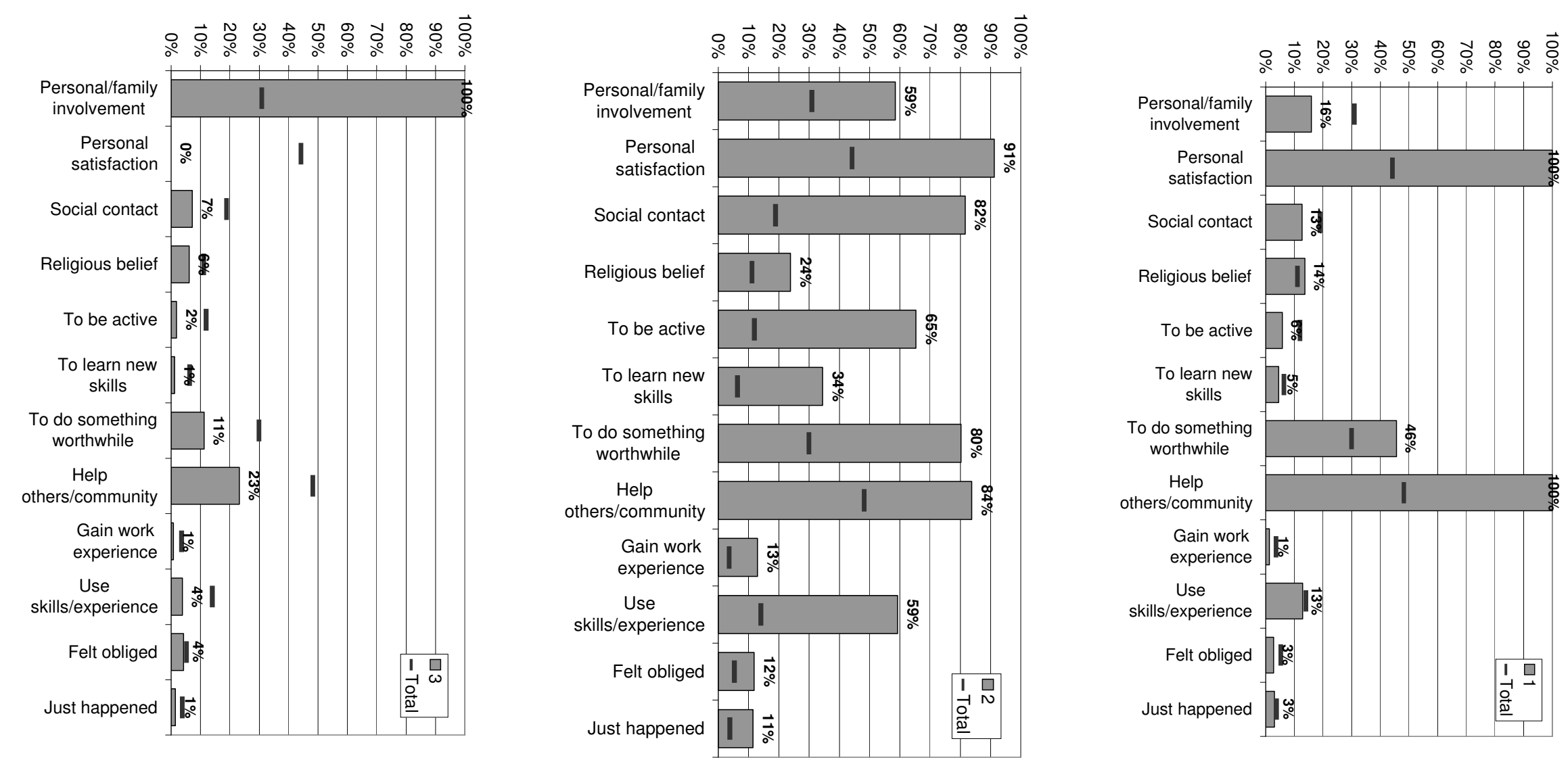


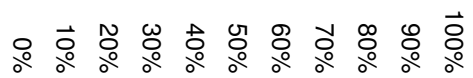

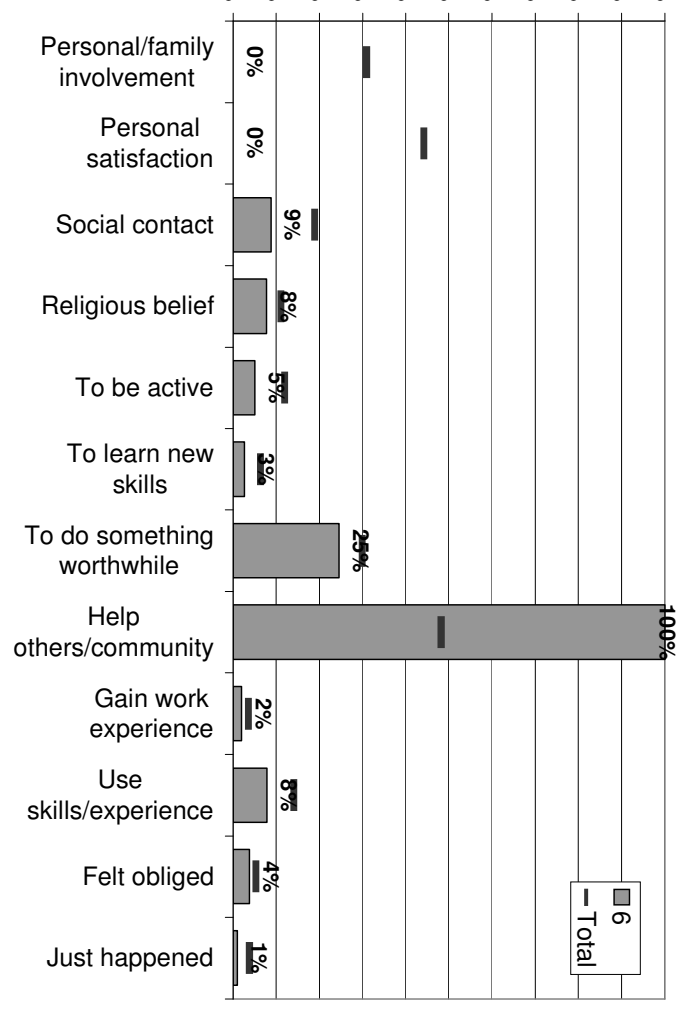

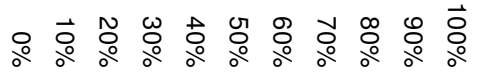

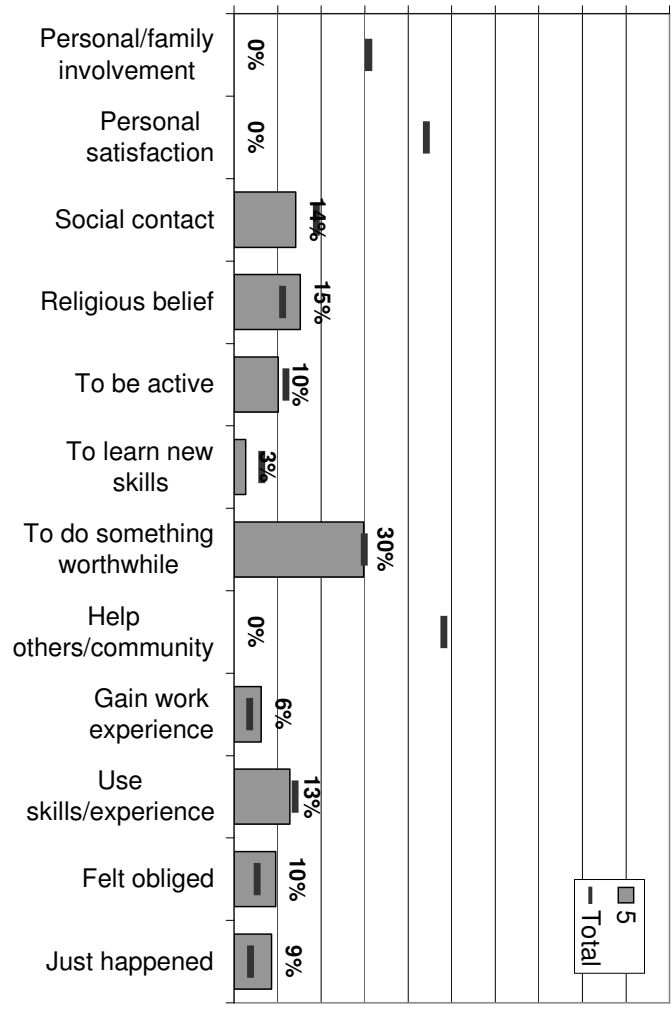

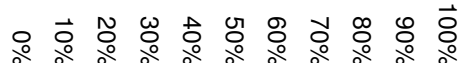

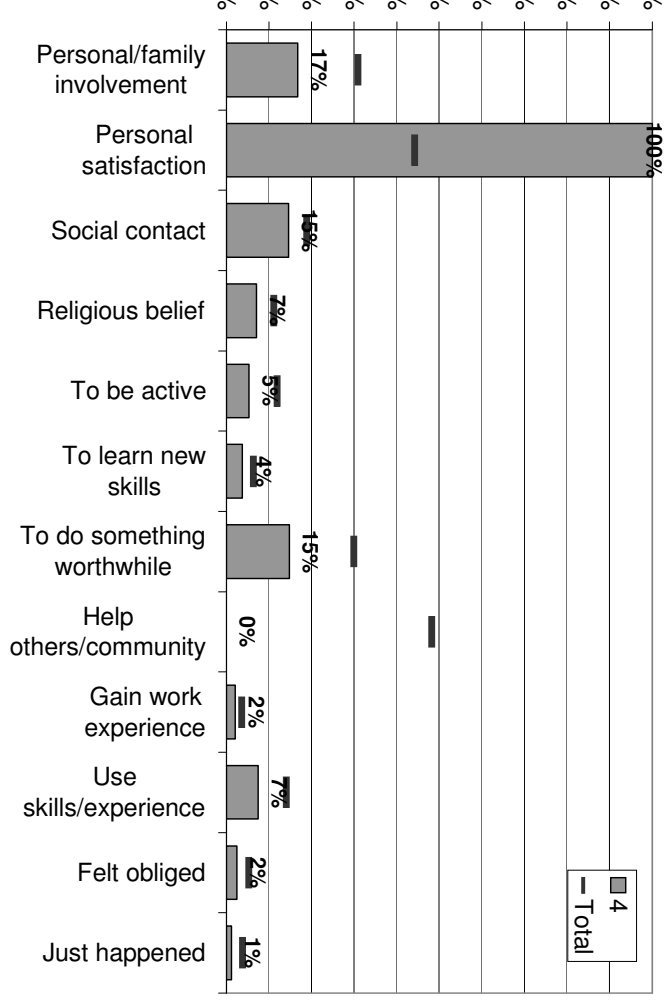


Based on these charts the segments are interpreted as follows. The motivations of segment 1 (15\% of the sample, $14 \%$ of the Australian volunteering population) are three-fold: doing something worthwhile, personal satisfaction, and helping others. This represents a typical volunteering motivation pattern, where the latter two motives are actually stated by every single one of the members of this market segment. Because this segment identifies with the motives typically stated by individuals who donate their time, the segment is labeled "classic volunteers".

Segment 2 (11\% of the sample, $10 \%$ of the population) was initially suspected to be an answer tendency, as these individuals state every single reason on the list more frequently than the total sample of volunteers. Through the external validation with background variables, however, it becomes evident that this segment is indeed a specific type of volunteer, probably the most dedicated one, consequently referred to as "dedicated volunteers". All members of segment 3 (19\% of the sample, $21 \%$ of the population, "personally involved volunteers") agree that there is only one reason to volunteer: personal involvement. On the other hand, not a single one states that they derive any sort of personal satisfaction by working as volunteers.

The contrary is the case for segment 4 (20\% of the sample, $20 \%$ of the population, "volunteers for personal satisfaction"). This segment seems to be almost egoistically motivated to volunteer, as personal satisfaction drives members of this group, whereas helping others is perceived as completely irrelevant.

Segment 5 (16\% of the sample, $16 \%$ of the population) demonstrate above-average agreement with motivations such as feeling obliged to volunteer and getting into the volunteering activity almost by accident, but they also state that gaining work experience and religious 
beliefs motivate them to engage in unpaid work. Due to this high level of heterogeneity, they are referred to as "niche volunteers".

Finally, segment 6 (20\% of the sample, $20 \%$ of the population) are the "altruists". They are primarily concerned with helping others.

It should be mentioned at this point, that the volunteer data does not demonstrate the typical pattern frequently occurring when partitioning data of collecting negative and positive answer tendencies in two clusters. All segments derived from analysis are fully interpretable.

The volunteering data set provided by the ABS also includes a wide variety of sociodemographic and behavioral information that can be used to describe and externally validate the segments resulting from this study. As all the variables included in the data set are categorically or ordinal scaled, Chi-squared tests were computed for variables of interest and the p-values Bonferroni corrected to account for multiple testing on the same data. The results are given in Table I, which includes the percent values within the segments. Please note that wherever percentages do not sum up to 100, options like "other" or "not applicable" have been offered to the respondents in the questionnaires, which are not included in the table. 
Table I: Background Variables Used to Describe and Externally Validate Segments

\begin{tabular}{|c|c|c|c|c|c|c|}
\hline & & 12 & 345 & 6 & total & $\begin{array}{c}\text { Bonferroni } \\
\text { corrected } \\
\text { Chi }^{2}\end{array}$ \\
\hline \multirow[t]{2}{*}{ Sex } & Male & 4743 & 424851 & 52 & 47 & $<0.001$ \\
\hline & Female & 5357 & 585249 & 48 & 53 & \\
\hline \multirow[t]{14}{*}{ Household classification } & Couple family with children $0-14$ & 2735 & 642725 & 23 & 34 & $<0.001$ \\
\hline & Couple family with dep students $15-24$ & 79 & 7109 & 11 & 9 & \\
\hline & Couple family with non-dep children & 105 & 6106 & 8 & 8 & \\
\hline & Couple family no children-fem $<25$ & 22 & 132 & 2 & 2 & \\
\hline & Couple family no children-fem $25-44$ & 45 & 265 & 9 & 5 & \\
\hline & Couple family no children-fem 45-64 & 1612 & 51412 & & 12 & \\
\hline & Couple family no children-fem $65+$ & 98 & 366 & 8 & 6 & \\
\hline & One-parent with children 0-14 & 55 & 423 & 3 & 3 & \\
\hline & One parent with dep students $15-24$ & 11 & 112 & 1 & 1 & \\
\hline & One parent with non-dep children & 53 & 133 & 2 & 3 & \\
\hline & Other family & $0 \quad 1$ & $\begin{array}{lll}0 & 1 & 2\end{array}$ & 0 & 1 & \\
\hline & Multi family household & 10 & $\begin{array}{lll}3 & 2 & 3\end{array}$ & 1 & 2 & \\
\hline & Lone person household & 1111 & 21014 & 12 & 10 & \\
\hline & Group household & 43 & 247 & 3 & 4 & \\
\hline \multirow[t]{13}{*}{ Age 5 year groupings } & $18-19$ years & 33 & 267 & 4 & 4 & $<0.001$ \\
\hline & $20-24$ years & 56 & $4 \quad 8 \quad 11$ & 9 & 7 & \\
\hline & $25-29$ years & 76 & 889 & 7 & 8 & \\
\hline & $30-34$ years & 810 & 14810 & 9 & 10 & \\
\hline & 35-39 years & 1114 & 23139 & 9 & 14 & \\
\hline & 40-44 years & 1013 & 201010 & 11 & 13 & \\
\hline & 45-49 years & 1011 & 11129 & 10 & 11 & \\
\hline & $50-54$ years & 1511 & $\begin{array}{lll}6 & 8 & 8\end{array}$ & 12 & 10 & \\
\hline & $55-59$ years & 104 & 476 & 9 & 7 & \\
\hline & $60-64$ years & 58 & $\begin{array}{lll}3 & 6 & 7\end{array}$ & 7 & 6 & \\
\hline & 65-69 years & 95 & 246 & 5 & 5 & \\
\hline & 70-74 years & 34 & 254 & 5 & 4 & \\
\hline & 75 years or more & 45 & 143 & 4 & 3 & \\
\hline \multirow[t]{2}{*}{ Born in/outside Australia } & Born in Australia & 8082 & 797473 & 78 & 77 & $<0.001$ \\
\hline & Born outside Australia & 2018 & 212627 & 22 & 23 & \\
\hline \multirow[t]{4}{*}{ Employment status } & Wage or salary earner & 4949 & 585449 & 52 & 53 & $<0.001$ \\
\hline & Business - with emp & 65 & $\begin{array}{lll}7 & 5 & 8\end{array}$ & 8 & 7 & \\
\hline & Business - w/out emp & 109 & 111010 & 11 & 10 & \\
\hline & Not employed & 3435 & 243031 & 29 & 30 & \\
\hline \multirow[t]{4}{*}{ Highest qualification } & High school certificate or less & 3439 & 424742 & 43 & 42 & $<0.001$ \\
\hline & Certificate/Trade certificate & 3526 & 282726 & 26 & 28 & \\
\hline & Associate or undergraduate diploma & 1012 & 979 & 10 & 9 & \\
\hline & Bachelors degree or higher & 2022 & 201922 & 20 & 20 & \\
\hline \multirow[t]{6}{*}{ Household income } & Lowest $10 \%$ & 44 & 143 & 4 & 3 & $<0.001$ \\
\hline & 2nd decile & 63 & 256 & 6 & 5 & \\
\hline & 3rd decile & 66 & $\begin{array}{lll}5 & 7 & 8\end{array}$ & 6 & 6 & \\
\hline & 4 th decile & 78 & $\begin{array}{lll}6 & 6 & 9\end{array}$ & 6 & 7 & \\
\hline & 5 th decile & 97 & 656 & 7 & 7 & \\
\hline & 6th decile & 711 & $9 \quad 104$ & 7 & 8 & \\
\hline
\end{tabular}




\begin{tabular}{|c|c|c|c|c|}
\hline & 7th decile & 111214121110 & 12 & \\
\hline & 8th decile & 1011108109 & 10 & \\
\hline & 9th decile & $\begin{array}{llllll}11 & 9 & 13 & 9 & 8 & 11\end{array}$ & 10 & \\
\hline & Highest $10 \%$ & 10919121214 & 13 & \\
\hline \multirow[t]{5}{*}{ \# of organizations volunteered for } & One & 554269707765 & 65 & $<0.001$ \\
\hline & Two & 263320221620 & 22 & \\
\hline & Three & $141696 \quad 5 \quad 10$ & 9 & \\
\hline & Four & $\begin{array}{llllll}3 & 3 & 2 & 2 & 1 & 2\end{array}$ & 2 & \\
\hline & Five or more & $\begin{array}{llllll}2 & 6 & 1 & 0 & 0 & 3\end{array}$ & 2 & \\
\hline \multirow[t]{5}{*}{ Volunteering-related expenses } & Phone calls & 506237423336 & 42 & $<0.001$ \\
\hline & Postage & 243014141215 & 17 & $<0.001$ \\
\hline & Uniform & $\begin{array}{llllll}7 & 10 & 3 & 6 & 3 & 2\end{array}$ & 5 & $<0.001$ \\
\hline & Travel costs & 566638433542 & 45 & $<0.001$ \\
\hline & Meals & 19257121013 & 13 & $<0.001$ \\
\hline \multirow[t]{2}{*}{ Reimbursement available } & Yes & 222011161213 & 15 & \\
\hline & No & 485942433844 & 44 & \\
\hline \multirow[t]{4}{*}{$\begin{array}{l}\text { Length of time since first } \\
\text { volunteered }\end{array}$} & Less than 1 year & $\begin{array}{llllll}6 & 5 & 8 & 8 & 12 & 9\end{array}$ & 8 & \\
\hline & $1-5$ years & 221633313726 & 29 & \\
\hline & $6-10$ years & 151618141214 & 15 & \\
\hline & More than 10 years & 192421181719 & 19 & \\
\hline \multirow[t]{5}{*}{ How first became involved } & Knew someone involved & 131219161313 & 15 & \\
\hline & Someone asked me & 13918171918 & 16 & \\
\hline & Self involvement in organization & 771512168 & 11 & \\
\hline & Saw ad/report in media & $\begin{array}{llllll}2 & 2 & 1 & 2 & 3 & 2\end{array}$ & 2 & \\
\hline & Found out about it myself & $\begin{array}{llllll}5 & 2 & 2 & 5 & 4 & 6\end{array}$ & 4 & \\
\hline \multirow[t]{4}{*}{ Labor force status } & Employed full-time & 434146484452 & 46 & $<0.001$ \\
\hline & Employed part-time & 242430232519 & 24 & \\
\hline & Unemployed & $\begin{array}{llllll}4 & 4 & 4 & 2 & 5 & 2\end{array}$ & 3 & \\
\hline & Not in the labor force & 293121272627 & 26 & \\
\hline \multirow[t]{6}{*}{ Hours volunteered in the last year } & Less than 20 & 9626192728 & 21 & $<0.001$ \\
\hline & 20 to less than 40 & 13616121417 & 14 & \\
\hline & 40 to less than 80 & 161620201815 & 18 & \\
\hline & 80 to less than 140 & 151717151412 & 15 & \\
\hline & 140 to less than 300 & 252813201412 & 18 & \\
\hline & 300 hours or more & 22278121214 & 15 & \\
\hline \multirow[t]{9}{*}{ Main type of voluntary activity } & Admin/clerical/recruitment & $\begin{array}{llllll}0 & 1 & 1 & 0 & 0 & 1\end{array}$ & 1 & \\
\hline & Coaching/refereeing/judging & $\begin{array}{llllll}1 & 0 & 0 & 0 & 0 & 1\end{array}$ & 0 & \\
\hline & Befriending/supportive listening counsel & $\begin{array}{llllll}1 & 1 & 0 & 1 & 0 & 2\end{array}$ & 1 & \\
\hline & Fundraising/sales & $\begin{array}{llllll}1 & 2 & 1 & 0 & 0 & 1\end{array}$ & 1 & \\
\hline & Preparing/serving food & $\begin{array}{llllll}1 & 1 & 1 & 0 & 0 & 0\end{array}$ & 0 & \\
\hline & Repairing/maintenance/gardening & $\begin{array}{llllll}0 & 1 & 0 & & 0 & 1\end{array}$ & 0 & \\
\hline & Management/committee work/co-ordination & $\begin{array}{llllll}2 & 4 & 1 & 1 & 1 & 2\end{array}$ & 2 & \\
\hline & Personal care/assistance & $\begin{array}{llllll}1 & 1 & 0 & 0 & 0 & 0\end{array}$ & 0 & \\
\hline & Teaching/instruction/providing information & $\begin{array}{llllll}3 & 2 & 1 & 1 & 1 & 2\end{array}$ & 1 & \\
\hline
\end{tabular}


As can be seen in Table I, "classic volunteers" are one of the older groups of volunteers. More than half of them are over 45 , more than one fifth above 60 . The vast majority of members of this group are born in Australia, and more than a third is not employed (anymore). They are one of two groups who incur high expenses from their volunteering activity, about one fifth has some opportunity to claim those back. They are very active volunteers, with almost half of them investing more than 140 hours a year into volunteering activities. Teaching, instruction and providing information as well as coordinating work or being committee members are their main contributions to the organizations to which they donate their time.

The "dedicated volunteers" have a very similar pattern to the classic volunteers, however, they are more strongly female dominated, have the highest proportion of members with university level education, and one third is not in the labor force. The determination and passion of this segment for volunteering is clearly supported by their volunteering behavior: these people donate their time to no less than six volunteering organizations, 55 percent work more than 140 hours a year, 27 percent of which work more than 300 . They incur the highest expenses through their volunteering activity (for which 60 percent do not get reimbursed) and their main activities are management, committee membership, co-ordination, fundraising and providing information. A quarter of the members of this segment have been volunteering for more than 10 years.

The "personally involved volunteers" are entirely different. They have the highest proportion of wage or salary earners among their members, represent the highest household income segment and include most part-time workers. They contribute to one volunteering organization only and invest the least hours of all segments into their activity. They volunteer because they know someone involved in the organization, very likely their child, as two thirds of the members of this group are couples aged between 30 and 44 with children. This segment has the highest proportion of women, probably mums. 
The "volunteers for personal satisfaction" do not demonstrate a very distinct profile. The only stand-out characteristics are that a very high proportion of them are not born in Australia, and they have the lowest level of education.

"Niche volunteers" have an atypically low proportion of women, leading to an equal distribution between men and women in this segment. A high proportion of these volunteers live alone, and almost one fifth is younger than 24 years, thus making this group the youngest segment. It has the highest proportion of members not born in Australia and the highest proportion with a university education. They typically help one organization only, have not been volunteering for many years and contribute relatively few hours each year to their volunteering activity.

Equally many men are "altruists" as women. Their socio-demographic pattern does not demonstrate any strong deviations from the total volunteering population with one third being aged between 40 and 54 and half of them earning a wage or salary. In terms of their volunteering activity they contribute to three organizations on average, which makes them the second most dedicated group in terms of involvement, although the hours they spend helping out are among the lowest of all segments. The hours they do donate they spend befriending and listening to people, managing and coordinating as well as teaching and passing on information.

\section{$\underline{\text { Conclusions and Limitations }}$}

While there has been much research on motivations for volunteering most attempts at segmenting volunteers have simply described volunteers or investigated differences based on a priori selected criteria assumed to influence volunteering behavior, for example age, sex or race. This study extends the somewhat limited number of data driven (a posteriori, post-hoc) market segmentation studies of volunteers, using 12 stated motivations for volunteering to 
determine homogeneous subgroups among volunteers who might represent useful targets for customized marketing, thus helping volunteering organizations more successfully recruit new members.

Six segments were found to be the most stable solution and can briefly be characterized as follows: "classic volunteers" are involved to do something worthwhile, gain personal satisfaction, and help others. They are older, less frequently active in the workforce, and very active in their volunteering efforts. They are, however, outperformed by the "dedicated volunteers" who contribute the most hours per year to an average of six volunteering organizations. Alternatively, "personally involved volunteers" appear to participate in the volunteering industry only temporarily, as long as (most probably) their child is part of an organization that relies on parental support. "Volunteers for personal satisfaction" and "altruists" are motivated by gaining their own satisfaction and represent the least distinct segments, with "altruists" doing the most work in the area of befriending and listening to people. Finally, "niche volunteers" are young, new to the volunteering industry, highly educated and state a variety of rather atypical reasons for volunteering, like feeling obliged to volunteer and having slid into volunteering rather passively, gaining work experience or religious beliefs.

The segments identified demonstrate clear and distinct motivational patterns and differ significantly from each other regarding background variables of both a sociodemographic and behavioral nature. Managers charged with the responsibility of recruiting Australian volunteers can be confident that these descriptions represent significant groups of volunteers and form an interesting basis for targeted marketing action. Essentially, what this means is that instead of developing generic recruitment campaigns which are expensive and of limited meaning to many of the individuals they actually reach, managers of volunteering organisations can make better and more efficient use of their limited marketing dollars. They 
can do this by designing campaigns specifically targeted at those groups of the market they have the most chance of attracting with messages that are the most meaningful and motivating for them.

For instance, communication messages aimed at segment five, "niche volunteers", should contain appeals regarding the potential for leaning new skills or highlight the agency's affiliation with religious organisations, whereas the likelihood of attracting volunteers from segment six, "altruists', will increase by informing them about the selfless and humanitarian aims of the organisation.

Contrary to Shelley \& Polonsky's (2002) research, this study has found significant differences between the six segments identified, which demonstrate distinct motivational patterns and demographic profiles. The recommendations of specific and targeted marketing messages which have resulted from this study therefore directly contradict those suggested by Shelley and Polonsky. This could be due to the different sample profiles and sizes involved, however future studies which investigate this discrepancy would be beneficial for practitioners.

Some segments did show consistency with certain demographic and attitudinal findings of previous studies, for example the high levels of employed volunteers found in segments three and four (consistent with the findings of Auslander \& Litwin, 1988; Curtis, Grabb, \& Baer, 1992; Smith, 1994); and the particularly altruistic attitudes found in segment six (as suggested by Florin, Jones, \& Wandersman, 1986; Reed \& Selbee, 2000). However due to the very distinct profiles which emerged for each segment, it is hard to find broad correlations between the findings of prior studies and the six segments identified here. This illustrates the added value of the data-driven segmentation approach in addressing the recruitment problem being faced by modern volunteering organisations. 
The results of this study do, however, have limited potential for generalization to other countries as the data set used only includes Australian volunteers. Beyond the borders of Australia, the findings can be seen as hypotheses generating only. Furthermore, the authors were not involved in the design of the questionnaire or the collection of the data set which ultimately formed the basis for the segmentation study.

Future work should include a cross-national study of volunteering segments to determine whether homogeneous subgroups of the nature described above can be identified on other continents or whether their existence is dependent on the local culture in which volunteering decisions are made. Furthermore, to increase the value of segmentation studies in the area of volunteering, a number of additional behavioral questions should be asked. This would enable the development of a very precise profile that would make it possible to not only understand different volunteer sub-segments but also to target them more efficiently. 


\section{Acknowledgements}

This research is supported by the Australian Research Council through the Linkage Grant

Scheme (LP0453682) and our industry partner, Bushcare Wollongong, a division of

Wollongong City Council. We would particularly like to thank Paul Formosa, Natural Areas

Coordinator for Wollongong City Council, for his support and assistance with this project. 


\section{$\underline{\text { References }}$}

Ajzen, I. (1988). Attitudes, Personality and Behaviour. Milton-Keynes, England: Open University Press.

Anderson, J. C., \& Moore, L. F. (1978). The Motivation to Volunteer. Journal of Voluntary Action Research, 7(1), 120-129.

Auslander, G. K., \& Litwin, H. (1988). Sociability and Patterns of Participation: Implications for Social Service Policy. Journal of Voluntary Action Research, 17(2), 25-37.

Australian Bureau of Statistics. (2001). Voluntary Work, Australia 2000. Retrieved 8 June, 2004, from http://www.ausstats.abs.gov.au/ausstats/subscriber.nsf/Lookup/5C22B0F4DCB4CB5 CCA256A7100047040/\$File/44410_2000.pdf

Bales, K. (1996). Measuring the Propensity to Volunteer. Social Policy \& Administration, 30(3), 206-226.

Berger, I. E. (2006). The Influence of Relgion on Philanthorpy in Canada. Voluntas: International Journal of Voluntary and Nonprofit Organizations, 17(2), 115-132.

Buchta, C., Dimitriadou, E., Dolnicar, S., Leisch, F., \& Weingessel, A. (1997). A Comparison of Several Cluster Algorithms on Artificial Binary Data Scenarios From Travel Market Segmentation.Unpublished manuscript, Vienna.

Bussell, H., \& Forbes, D. (2002). Understanding the Volunteer Market: The What, Where, Who and Why of Volunteering. International Journal of Nonprofit and Voluntary Sector Marketing, 7(3), 244-257. 
Chinman, M. J., \& Wandersman, A. (1999). The Benefits and Costs of Volunteering in Community Organisations: Review and Practical Implications. Nonprofit and Voluntary Sector Quarterly, 28(1), 46-64.

Clary, E. G., Ridge, R. D., Stukas, A. A., Snyder, M., Copeland, J., Haugen, J., et al. (1998). Understanding and Assessing the Motivations of Volunteers: A Functional Approach. Journal of Personality and Social Psychology, 74(6), 1516-1530.

Clary, E. G., \& Snyder, M. (1999). The Motivations to Volunteer: Theoretical and Practical Considerations. Current Directions in Psycholgocial Science, 8(5), 156-159.

Clary, E. G., Snyder, M., \& Ridge, R. (1992). Volunteers' Motivations: A Functional Strategy for the Recruitment, Placement, and Retention of Volunteers. Nonprofit Management and Leadership, 2(4), 333-350.

Clary, E. G., Snyder, M., \& Stukas, A. A. (1996). Volunteers' Motivations: Findings from a National Survey. Nonprofit and Voluntary Sector Quarterly, 25(4), 485-505.

Courtney, R. (1994). Directions in Voluntary Sector Management. Management Development Review, 7(3), 33-36.

Curtis, J. E., Grabb, E. G., \& Baer, D. E. (1992). Voluntary Association Membership in Fifteen Countries: A Comparative Analysis. American Sociological Review, 57(2), $139-152$.

Dolnicar, S. (2004). Beyond "Commonsense Segmentation" - a Systematics of Segmentation Approaches in Tourism. Journal of Travel Research, 42(3), 244-250.

Everitt, B. S., Landau, S., \& Leese, M. (2001). Cluster Analysis. New York: Oxford University Press. 
Ewing, R. L., Govekar, M. A., Govekar, P. L., \& Rishi, M. (2002). Economics, Market Segmentation and Recruiting: Targeting Your Promotion to Volunteers' Needs. Journal of Nonprofit and Public Sector Marketing, 10(1), 61-76.

Florin, P., Jones, E., \& Wandersman, A. (1986). Black Participation in Voluntary Associations. Journal of Voluntary Action Research, 15(1), 65-86.

Greenslade, J. H., \& White, K. M. (2005). The Prediction of Above-Average Participation in Volunteerism: A Test of the Theory of Planned Behavior and the Volunteer Functions Inventory in Older Australian Adults. The Journal of Social Psychology, 145(2), 155172.

Heidrich, K. W. (1990). Volunteers Life-Styles: Market Segmentation Based on Volunteers' Role Choices. Nonprofit and Voluntary Sector Quarterly, 19(1), 21-31.

Heinz, D., \& Robinson, R. K. (1999). Nonprofits Need Surveys in Order to Serve Better. Marketing News, 33(12), H36.

Hibbert, S., Piacentini, M., \& Dajani, H. A. (2003). Understanding Volunteer Motivation for Participation in a Community-Based Food Cooperative. International Journal of Nonprofit and Voluntary Sector Marketing, 8(1), 30-42.

Kotler, P. (1975). Marketing for Nonprofit Organizations. New Jersey: Prentice-Hall.

Lemon, M., Palisi, B. J., \& Jacobson, P. E. (1972). Dominant Statuses and Involvement in Formal Voluntary Associations. Journal of Voluntary Action Research, 1(2), 30-42.

Liao-Troth, M. A., \& Dunn, C. P. (1999). Social Constructs and Human Service: Managerial Sensemaking of Volunteer Motivation. Voluntas: International Journal of Voluntary and Nonprofit Organizations, 10(4), 345-361. 
Marta, E., Guglielmetti, C., \& Pozzi, M. (2006). Volunteerism During Young Adulthood: An Italian Investigation into Motivational Patterns. Voluntas: International Journal of Voluntary and Nonprofit Organizations, 17(3), 221-232.

Martinetz, T., \& Schulten, K. (1994). Typology Representing Networks. Neural Networks, $7(5), 507-522$.

Mazanec, J. (2000). Market Segmentation. In J. Jafari (Ed.), Encyclopedia of Tourism. London: Routledge.

McDonald, M. (2002). Marketing Plans - How to Prepare Them, How to Use Them (4th ed.). Oxford: Butterworth-Heinemann.

McPherson, J. M., \& Rotolo, T. (1996). Testing a Dynamic Model of Social Composition: Diversity and Change in Voluntary Groups. American Sociological Review, 61(2), 179-202.

Menchik, P. L., \& Weisbrod, B. A. (1987). Volunteer Labor Supply. Journal of Public Economics, 32(2), 159-183.

Okun, M. A., Barr, A., \& Herzog, A. R. (1998). Motivation to Volunteer by Older Adults: A Test of Competing Measurement Models. Psychology and Ageing, 13(4), 608-621.

Ordway, C. J. (2000). Characteristics of Giving. Fund Raising Management, 31(7), 28-32.

Reed, P. B., \& Selbee, L. K. (2000). Distinguishing Characteristics of Active Volunteers in Canada. Nonprofit and Voluntary Sector Quarterly, 29(4), 571-592. 
Rehberg, W. (2005). Altruistic Individualists: Motivations for International Volunteering Among Young Adults in Switzerland. Voluntas: International Journal of Voluntary and Nonprofit Organizations, 16(2), 109-122.

Riecken, G., Babakus, E., \& Yavas, U. (1994). Facing Resource Attraction Challenges in the Nonprofit Sector: A Behavioristic Approach to Fund Raising and Volunteer Recruitment. Journal of Professional Services Marketing, 11(1), 45-70.

Shelley, L., \& Polonsky, M. J. (2002). Do Charitable Causes Need to Segment Their Current Donor Base on Demographic Factors?: An Australian Examination. International Journal of Nonprofit and Voluntary Sector Marketing, 7(1), 19-29.

Smith, D. H. (1994). Determinants of Voluntary Association Participation and Volunteering: A Literature Review. Nonprofit and Voluntary Sector Quarterly, 23(3), 243-263.

Smith, D. H., Macauley, J., \& Associates. (1980). Participation in Social and Political Activities. San Francisco: Jossey-Bass.

Volunteering Australia. (2001). A National Agenda on Volunteering: Beyond the International Year of Volunteers. Retrieved 7 April, 2004, from http://www.volunteeringaustralia.org/publications/nat_agenda.html

Wilson, A., \& Pimm, G. (1996). The Tyranny of the Volunteer: The Care and Feeding of Voluntary Workforces. Management Decision, 34(4), 24-40.

Wymer, W. W. (1997). Segmenting Volunteers Using Values, Self-Esteem, Empathy, and Facilitation as Determinant Variables. Journal of Nonprofit and Public Sector Marketing, 5(2), 3-28. 
Wymer, W. W. (2003). Differentiating Literacy Volunteers: A Segmentation Analysis for Target Marketing. International Journal of Nonprofit and Voluntary Sector Marketing, 8(3), 267-285.

Yeung, A. B. (2004). The Octagon Model of Volunteer Motivation: Results of a Phenomenological Analysis. Voluntas: International Journal of Voluntary and Nonprofit Organizations, 15(1), 21-46. 